\title{
THE SIZE OF STATES OF THE GAP TECHNOLOGICAL IN DEVELOPING COUNTRIES COMPARED TO THE STATES OF ADVANCED
}

Aswan Abdul Qader Zaidan

Department of Agricultural Economics - College of Agriculture and Forestry University of Mosul

\begin{abstract}
Technological progress is one of the main and important factors in accelerating the economic, social and cultural growth of different countries. It is the most common denominator of various economic development processes, foremost of which is agricultural development and increasing productivity then productivity in the agricultural sector. In terms of measuring the technological gap in developing and advanced countries in Iraq, Syria, Italy, and Japan, the results of technology gap analysis indicated an average of 49, 38, 29, 22\% (for Iraq, Syria, Italy and Japan) Mine.The study concluded with a number of conclusions, including the low competitiveness of most developing countries, low production and low quality due to the high costs resulting from the high prices of production inputs, as well as the apparent low rates of use of agricultural technology both for the use of tractors and machinery or the use of chemical fertilizers, Irrigation and the use of improved varieties in agriculture, Therefore, the study recommends that developing countries should pay attention to the scientific and technological aspects that support the development of agricultural production and intensify the effort to formulate economic development policies that are in line with their reality and their potential. Key Words :Technical Gap, Developing Countries ,Advanced Countriese
\end{abstract}

Received:24/9/2018, Accepted: 7/11/2018

\section{INTRODUCTION}

Both advanced and developing countries have the technological potential to achieve remarkable progress in various fields, especially in the agricultural sector and achieve development and economic growth, which is reflected in the high standard of living and welfare within the country. The importance of technology in advanced countries is to achieve high rates of growth, While the importance of technology in developing countries as a means to save them from the manifestations of economic underdevelopment, and reduce the food gap and then the technological gap between them and advanced countries and try to increase exports, which contributes to increase the degree of competitivenessat the international level.

The research aims to:

1- to explore the reality of the agricultural sectors in sample countries in order to diagnose differences causes in the size of the technological gap and try to focus on the factors of raising efficiency and productivity in advanced countries to propose as a saving recipe for agricultural sectors incountries .

2- try to measure the size of the technological gap for each of the advanced and developing countries and compare them within the duration of the study period (19852017). 
The problem of research includethe rapid change in knowledge and the increase in technological applications, both qualitative and quantitative, are characteristic of the advanced countries. This is accompanied by a significant backwardness in developing countries, resulting in a clear technological gap, one of the problems that hinders the planning of the agricultural sector in these countries. The research is based on hypothesis that the diagnosis of overall efficiency and productivity then the size and comparison of the technological gap of both advanced and developing countries is the best way to plan sustainable agricultural development in developing countries.

The importance of research is the subject of technologicalprogress, which is one of the most important fundamentals responsible for the acceleration of economic growth, if not the most important, it is the common denominator of economic development processes, particularly agricultural development, as the subject of technology was and still is a ruling issue in the field of development for all advanced countries in general and developing ones in particular, so the countries have paid attention to technological development and bridging the gap between advanced and developing countries alike.

In the seventies of the last century and the global crisis in the food crisis, when the world was alerted to the dangers of growing gap between food demand and production rates, a gap that affects the developing world, primarily the Arab countries (Al-Rawi, 1987: 30), And the issue of food in fact is the influential side in the issue of agriculture Flo and accompanied by agriculture (plant and animal production) the growing demand for this production, mainly arising from the growing population and improve their standard of living, On the other hand, agriculture continued to express its food and other products at the same time, or at very best, its production increased at a modest rate, for several reasons, which stated that it had not received sufficient attention. In some developing countries, it was believed that food was available and available in the global market. Buy and can not pay the price.

The requirements for agricultural development in the past had been natural resources, human resources and capital. Now, this new element adds new technology, which leeds to the widening gap between the countries of the world.

Many countries that have mastered the modern technology have progressed and will continue to progress at a rapid rate, (Abdulsalam,1990: 7). Therefore, the disparity between developing and advanced countries and the gap between them is one of the topics that were and continue to represent the interest of the specialists and the people. Eye, however, the most important issue is why the developing countries did not become advanced after the Second World War and until now, progress indicates complex factors, including considerations of access to a sectorally diversified economy at the local and external levels, including high level of technological development in Economic growth as well as the decline of poverty and the development of social systems for the care of the unemployed (Jumaili, 1993: 85).Thus, the technological gap can be defined as the time lag between the emergence of new technologies and their acquisition in the country, the presence of technology in a country and its non-existence in other countries. The economic definition of Dharwad has been defined as a deviation from the recommended levels. Chitniz and Bhilegaonkar Drylands the average technological gap was higher 
for small farmers followed by medium and large-scale farms in land technology. The technological gap can be determined on the basis of a balance between the rates of using modern technologies such as improved seeds, chemical fertilizers, pesticides and mechanization for the medium farms and for the best farms in a particular geographic area characterized by their natural and social conditions. For example, a village can be balanced between medium farms and technical recommendations for extension fields However, the technical recommendations often failed to meet the social and economic conditions under which the farms operate. There are several studies dealing with the technological gap, including the study (Iyeer, 2006) in which he studied the determinants of technology 63 countries during the period (1982-2000) In the first stage, the technological gap between the individual countries and the global borders was measured. In the second stage, the growth rate, which is considered the indicator of technological catch, is found. In this study, the growth rate in a group of countries decreased by using many variables such as trade and foreign direct investment flows and human capital, so these countries should have positive effects that close the technological gap and accelerate the rate of productivity growth. In another study carried out by the researchers (Ansari and Mehdi, 2010) The research focuses on the dimensions of the qualitative economy through the structure of the theory of the technological economy under development. The importance of the research stems from the study of the technological gap. The new qualitative transformations, especially the dynamics of the economy environment based on information and technological knowledge, produce new perspectives and alternative options. (Al-Badri, 2012) in this study of the technological gap in the agricultural sector in Iraq. The results of the study showed that there is a technological gap in all fields of agricultural and mechanical technology Chemistry and biology.

Technological capabilities in advanced and developing countries: The countries of the advanced and developing world alike seek to acquire the technological capabilities that enable them to achieve remarkable progress in various fields and achieve economic growth and sustainability in the long term, reflecting the high standard of living and prosperity within the country (Ali and Hamid, 2010: 354). Including in terms of their ability to use, develop and improve innovations and modern technological methods, as well as in the ability of the state to localize modern technology within the various goods and products and production processes within the economic sectors, The technological potential of the state can be defined as the ability to use and effectively integrate technological knowledge. It includes all the skills available to the physical capital available in the economy, as well as the technological systems prevailing in the country at a certain point in time. The technological potential of the state is influenced by many factors that interact with each other These are include the size of physical capital in the agricultural sector, the efficiency of financial systems in financing and supporting other economic sectors, as well as the human capital, skills and experience gained as a result of Training and education).and the size of the front and back linkages of the agricultural sector where technological progress occurs.

The size of the technological gap varies from one country to another depending on the size of the technology prevailing in the economy, which varies according to the 
internal growth theory based on the different technological path of the country, the different periods of time studied and policies applied to increase the technological potential. The size of the technological gap between advanced and developing countries is affected by three main determinants:

1.The Size of technology prevailing in theeconomy.

2. Possibilities for innovation.

3 - possibilities of technology flow to different countries.

There are mechanisms of technological progress between advanced and developing countries. Table (1) shows that advanced countries and developing countries are less interested in the process of technological advancement. Advanced countries aim to increase technology by investing in technological innovations. They have the material and human resources and legislative systems to stimulate technological progress in order to meet the basic needs within the country by transferring or imitating the technology received from the advanced countries and settling them within the state with the low volume of material and human resources and skills necessary to achieve progress Technological changes and changes in the economic situation and policies within the state (Abu Saud, 2010: 5).

Table (1): The different mechanisms of technological progress in both advanced and developing countries

\begin{tabular}{|c|c|c|c|}
\hline & $\begin{array}{c}\text { Comparative } \\
\text { elements }\end{array}$ & Advanced countries & Developing countries \\
\hline 1 & $\begin{array}{l}\text { Reasons to pursue } \\
\text { technological } \\
\text { progress }\end{array}$ & $\begin{array}{l}\text { Achieve technological } \\
\text { increase and increase } \\
\text { economic growth rates }\end{array}$ & $\begin{array}{l}\text { Meeting the basic needs of } \\
\text { economic growth within } \\
\text { the country }\end{array}$ \\
\hline 2 & $\begin{array}{l}\text { Ways to achieve } \\
\text { technological } \\
\text { progress }\end{array}$ & $\begin{array}{l}\text { To carry out } \\
\text { technological } \\
\text { innovations and } \\
\text { research and } \\
\text { development activities } \\
\text { in scientific and } \\
\text { applied fields }\end{array}$ & $\begin{array}{l}\text { By transferring or } \\
\text { imitating technology from } \\
\text { advanced countries and } \\
\text { settling them within the } \\
\text { state }\end{array}$ \\
\hline 3 & $\begin{array}{l}\text { Sources of } \\
\text { technological } \\
\text { progress in the } \\
\text { country }\end{array}$ & $\begin{array}{l}\text { Major agricultural } \\
\text { enterprises conducting } \\
\text { R \& D activities }\end{array}$ & $\begin{array}{l}\text { Agricultural institutions } \\
\text { capable of importing or } \\
\text { imitating modern } \\
\text { technology from advanced } \\
\text { countries }\end{array}$ \\
\hline 4 & $\begin{array}{l}\text { Availability of raw } \\
\text { materials needed for } \\
\text { technological } \\
\text { progress }\end{array}$ & $\begin{array}{l}\text { The high volume of } \\
\text { material and human } \\
\text { resources faced by the } \\
\text { State to achieve } \\
\text { technological progress }\end{array}$ & $\begin{array}{l}\text { The low volume of } \\
\text { material and human } \\
\text { resources faced by the } \\
\text { State to achieve } \\
\text { technological progress }\end{array}$ \\
\hline
\end{tabular}

Source: United Nations Development Program 2010 
The countries of the world can be divided according to the index of technological achievement and as in Table (2)

Table (2) Division of the world according to the index of technological achievement

\begin{tabular}{|l|l|c|}
\hline & \multicolumn{1}{|c|}{ Countries } & $\begin{array}{c}\text { The technological } \\
\text { achievement }\end{array}$ \\
\hline 1 & $\begin{array}{l}\text { Leading countries (which are at the cutting edge } \\
\text { of technological innovations) such as the United } \\
\text { States, Japan and South Korea }\end{array}$ & Above 0.5 \\
\hline 2 & $\begin{array}{l}\text { Countries likely to become leaders (countries } \\
\text { with high investments in the human element and } \\
\text { pervasive by old technological innovations) } \\
\text { such as Spain, Italy, Malaysia, Mexico }\end{array}$ & $(0.35-0.49)$ \\
\hline 3 & $\begin{array}{l}\text { Technology-intensive countries (developing } \\
\text { countries that are accelerating the use of modern } \\
\text { technology) such as China, India, Brazil and } \\
\text { Syria }\end{array}$ & $(0.2-0.34)$ \\
\hline 4 & $\begin{array}{l}\text { Technology-marginalized countries (countries } \\
\text { that need a lot of effort to build human capital } \\
\text { skills and deploy new technology) such as } \\
\text { Pakistan, Sudan and Iraq }\end{array}$ & Less than 0.2 \\
\hline \hline
\end{tabular}

Source: United Nations Development Program 2010

\section{MATERIALS AND METHODS}

Description of the TG technology gap model:

The technological gap is the flip side of total productivity and technical efficiency. The increase in overall productivity and technical efficiency is less than the technological gap and vice versa, which requires measurement. There had been interest in measuring the technological gap in the introduction of modern methods of measurement, including the formal methods of Parametrie Methods. Stochastic Frontier Model, and Non-Parametric Methods, including Data Envelopment Analysis. N. Kamieu (2010). Technology gap and efficiency levels using SFA The output of any cultivar( ith) plant in the( jth) group can be expressed by the following equation:

$$
\mathrm{Yi}=\mathrm{e}^{\mathrm{xiB}+\mathrm{Vi}-\mathrm{Ui}} \text { ore }^{\mathrm{xiB}^{*+}+\mathrm{Vi}^{*}-\mathrm{Ui}^{*}}
$$

This relationship can be written as follows: 


$$
\frac{e^{x i B}}{e^{x i B *}} \frac{e^{V i}}{e^{V i *}} \frac{e^{-U i}}{e^{-U i *}}-\cdots-1(2) \mathrm{I}=
$$

The three ratios on the right of the equation are called the( TGR), the( RER) and the average technical efficiency (TER).

$$
\mathrm{TGR}=\frac{e^{x E}}{e^{x B *}}=\mathrm{e}-\mathrm{xi}\left(\mathrm{B}^{*}-\mathrm{B}\right)
$$

$$
\text { RER }=\text { evi-vi* }
$$

As:

$$
\mathrm{TGR}=\frac{R E R}{T E R}
$$

RER: The mean Stander Error Ratio

TER: The mean Technical Efficiency Ratio

Thus, equation (3) can be used to find the technological gap of the sample countries (Iraq, Syria, Italy, Japan) for the period 1985-2017.

The technical efficiency assessment (TE) is important for measuring the technological gap, using the SFA method for estimating technical efficiency and random error, obtaining realistic indicators of the efficiency of the Iraqi agricultural sector, and five inputs were adopted in measuring technical efficiency:

$\mathrm{X} 1$ Area of cultivated land (thousand hectares).

X 2 Agricultural workers (thousand inhabitants)

X 3 Total agricultural capital accumulation (million dollars) at constant prices

X 4 Mechanical Technology (A horsepower)

X 5 Chemical technology (quantity of fertilizers consumed by $\mathrm{kg} / \mathrm{ha}$ ).

And the effect of these variables on one product, the value of agricultural output $Y$ for (Iraq, Syria, Italy, Japan) and for the period (1985 - 2017).

\section{RESULTS AND DISCUSSION}

Results of the assessment of technological gap of agricultural sectors in (Iraq, Syria, Italy, Japan) for the period (2017-1985):

DEAP and Stochastic Frontier have been used to obtain technical proficiency (TER) and random error ratio (RER), from which they will measure and create the technological gap Table 4 (TGR) for Iraq, Syria, Italy, Japan (N.Kamieu) ), 2010)Before the technological gap is calculated, the average technical efficiency (TER) must be calculated.

Table (3): Average technical efficiency (TER) of agricultural sectors in (Iraq,Syria,Italy,Japan) For Period(1985-2017)

\begin{tabular}{|c|c|c|c|c|}
\hline & $1985-1995$ & $1996-2006$ & $2007-2017$ & $1985-2017$ \\
\hline Iraq & 0.92 & 0.87 & 0.85 & 0.88 \\
\hline Syria & 0.88 & 0.84 & 0.89 & 0.87 \\
\hline Italy & 0.96 & 0.95 & 0.91 & 0.95 \\
\hline Japan & 0.98 & 0.95 & 0.95 & 0.96 \\
\hline
\end{tabular}

Source: Prepared by the researchers based on the Frontier program 
After calculating the technical efficiency average (TER) and RER values obtained from Stochastic Frontier $(0.441,0.343,0.28,0.22)$ for (Iraq, Syria, Italy, Japan), respectively, Applying equation (3),

$$
\mathrm{TGR}=\frac{R E R}{T E R} \text { - ...... }
$$

Results are installed in Table (4)

Table (4): Technology gap for countries (Iraq,Syria, Italy,Japan) for the period

\begin{tabular}{|c|c|c|c|c|}
\hline & $1985-1995$ & $1996-2006$ & $2007-2017$ & $1985-2017$ \\
\hline Iraq & 0.47 & 0.50 & 0.51 & 0.49 \\
\hline Syria & 0.38 & 0.40 & 0.38 & 0.38 \\
\hline Italy & 0.29 & 0.29 & 0.30 & 0.29 \\
\hline Japan & 0.22 & 0.23 & 0.23 & 0.22 \\
\hline
\end{tabular}

Source: Based on equation (3)

Technical Gap\%

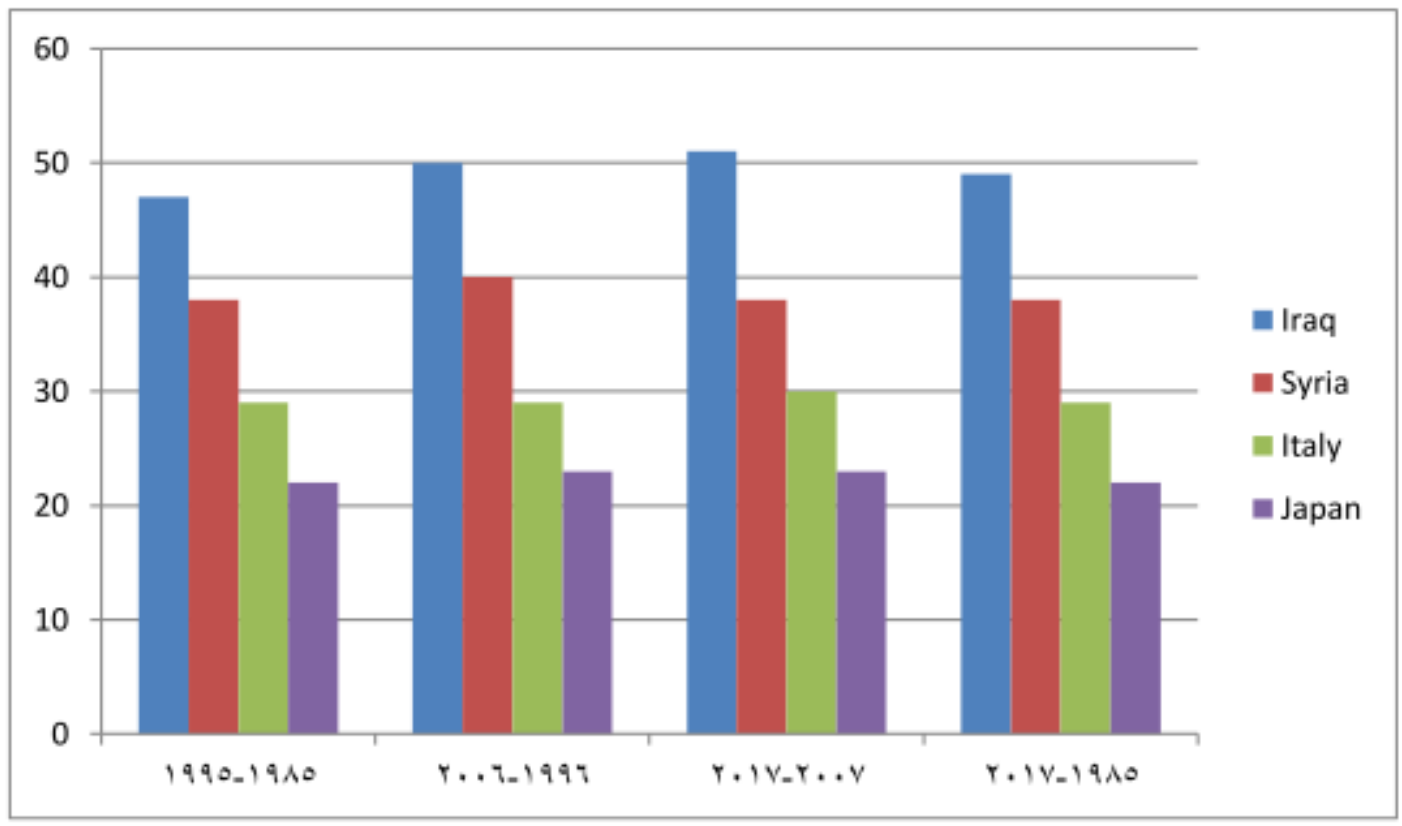

Period

Figure (1): Technology gap in the countries under consideration for the period 19852017

Figure 1 shows that there is a technological gap in the agricultural sector of Iraq for the period (1985-2017) when compared to the Arab and advanced countries, and this is already confirmed by the statistical data issued by the Ministry of Planning for the machinery and agricultural machinery (tractors) It was found that advanced countries use one tractor (50 dunums), while Iraq uses one tractor (151 dunums). In terms of harvesters, the advanced countries use one harvests (500 dunums), while Iraq uses one harvests (2090 dunums) Modern technology has created a gap between the areas covered by modern irrigation The area covered by conventional irrigation which is $99 \%$ In terms of fertilizer consumption, the gap between Iraq 
and the advanced countries is very high. In the Netherlands, there are $769 \mathrm{~kg} / \mathrm{ha}$ and $407 \mathrm{~kg}$ / ha in Japan, while only $43.78 \mathrm{~kg}$ / ha have reached Iraq. "For biotechnology, there is a technological gap in terms of low productivity agricultural crops compared to advanced and developing countries alike. For improved seeds, Iraq needs 193,000 tons and only 34,000 tons were available. Therefore, a large technological gap had been created. The lack of quality seeds remains one of the main obstacles that led to the decline in Iraq's productivity. Crop button Rodeo (Badri 1, 2012). In Syria, the gap is estimated to be about $38 \%$. The Syrian country has faced various environmental difficulties, mainly drought resulting from weak and intermittent rainfall, scarce water resources for irrigation development, poor management of crop and natural resources, and adoption of new technologies in the agricultural sector. At the national level, these technologies have spread among farmers, which have achieved a large increase in production and an abundance of cultivated area. Initial use of improved agricultural technologyIn wheat production during the period of study. This estimate amounted to about 22.265 billion Syrian pounds (equivalent to 540 million US dollars at 42 exchange rate). About $32 \%$ of this increase can be attributed to the use of improved varieties and $18 \%$ to the effect of fertilizer use $27 \%$ to irrigation effect, $23 \%$ to land and crop management factors, $33 \%$ to irrigated areas, $30 \%$ from irrigated areas and $38 \%$ from rainfed areas.

In Italy, the technological gap is estimated at $29 \%$, according this we concludes that Italy is one of the most powerful country in the world for premium products. The National Farmers' Union (FNU) points out that Italy is at the World Food Security Summit and it is the first European country in the organic plantations with 49070 organic companies in 2015 The output is up to 1.4 million tons and has the largest network of farms and farmers' markets in direct sales.

In Japan, the technological gap is estimated at 22\%. economically Japan is one of the most advanced countries in the world. Scientists are taking advantage of technological advances in devising food alternatives that save humans in the long term from starvation. The decline in arable land and the shortage of water resources that threaten drought. There is a dramatic development in the production of agricultural food in the closed areas due to progress in the field of solar energy, sensors and artificial intelligence. Closed farms have become viable alternatives instead of traditional farms outdoors. Thus, closed-loop farms are using water and land ten times less than traditional farms and produce more agricultural crops several times a year without relying on weather and without the use of harmful pesticides. This is a major leap in modern agriculture and the global agricultural revolution to cope with the food crisis and reduce the disasters Crops around the world.

From the above we conclude that production in most advanced countries exporting goods and services is based on the technological progress base so that the high production rates are a function of the level of development in this variable, and it uses the patterns of agricultural production and industrial capital intensive technology and the continuous pursuit of improving the varieties of agricultural products through the use of Genetic engineering and biological innovations that would clearly indicate a real revolution in contemporary agriculture expressed by 
increasing the productivity of the land and the development of new varieties of crops with abundant yield and excellent quality such as early maturity and resistance Diseases and epidemics, On the other hand, developing countries have been slowly absorbing these achievements. They suffer from backward production methods and low technology. This is due to the indifference of the technological variable on the one hand and the scientific research on the other, which is still suffering from high financial and debt problems. It is worth mentioning that the results of technological progress are unfairly distributed among the countries of the world as the advanced countries acquire 95\% of the technology while the developing countries receive the remaining part.The study concluded with a number of conclusions:

1. The technological gap in Iraq is estimated at $49 \%$, despite the availability of many components of agriculture in Iraq, but these elements are facing many problems that make them disproportionate and raise the productivity of the agricultural sector, as the development policies of the agricultural sector in Iraq was not integrated it focused on certain aspects such as marketing and irrigation channels and neglected other important aspects such as developing scientific research centers, producing improved seeds, expanding the use of mechanization, chemical fertilizers, etc., as well as the problem of desertification and salinity in agricultural lands, which led to adecline in productivity in some lands and deterioration in others.

2. In Syria, the results of the technological gap assessment indicate $38 \%$. It is concluded that the use of advanced agricultural techniques led to positive results in the agricultural sector, especially in terms of productivity and productivity of some crops in irrigated agriculture. Covering large areas in the cultivation of grains, vegetables and fruits.

3. The results of the technological gap assessment in Italy and Japan were $29.22 \%$ respectively, as they are among the most advanced countries in the field of technology.

4. The apparent decrease in the rates of agricultural technology in developing countries, whether in the use of tractors and machinery or the use of chemical fertilizers and pesticides, as well as the use of irrigation methods and the use of improved varieties in agriculture, which affected the future development in these countries compared to advanced countries.

Based on previous findings, the study recommends:

1- The need for developing countries to take care of the scientific and technological aspects that support the development of agricultural production by adopting the stages method as follows:

Phase I: Optimal use of available technology in the framework of available knowledge and available financial resources.

Phase II: Transfer of technology and international scientific expertise to the conditions of these countries, taking into account the industrial and agricultural characteristics of these countries.

Phase III: The stage of scientific research and development, which is an advanced stage that opens up unlimited horizons for the development of available technologies, which positively affect the overall production base. 
2 - The need to coordinate and intensify the effort among developing countries in order to formulate economic development policies in line with their feasibility and potential to take into account international variables politically, economically and technologically.

3. To send scientific competencies from experts, scientists and technicians from developing countries to advanced countries in order to acquire scientific knowledge in the field of mechanical and chemical industries.

\title{
THE SIZE OF STATES OF THE GAP TECHNOLOGICAL IN DEVELOPING COUNTRIES COMPARED TO THE STATES OF ADVANCED \\ Aswan Abdul Qader Zaidan
}

Department of Agricultural Economics - College of Agriculture and Forestry -

University of Mosul

Email:AswanZedan@yahoo.com

\begin{abstract}
الخلاصة

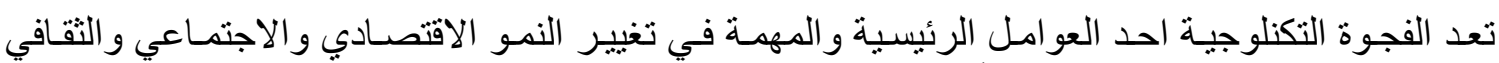

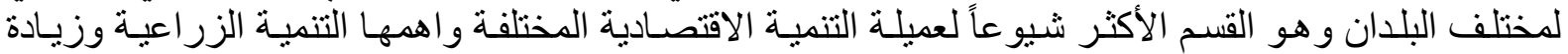

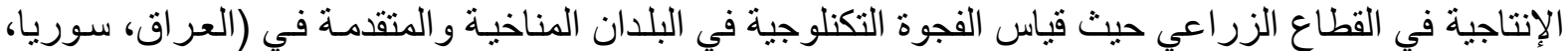

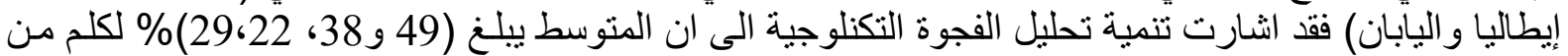

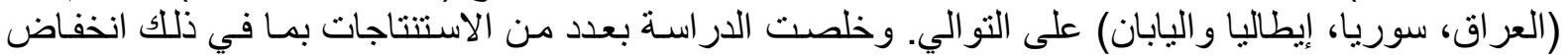

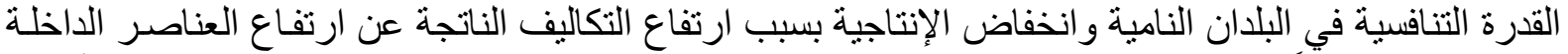

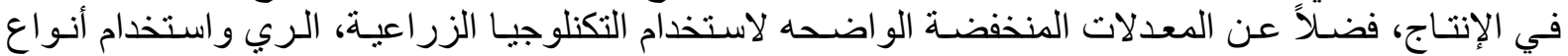

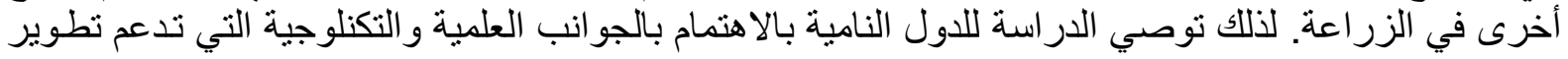

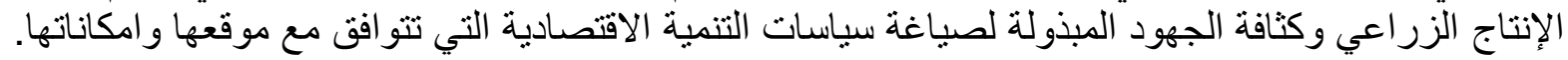

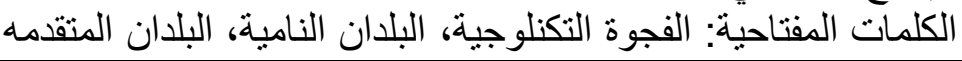

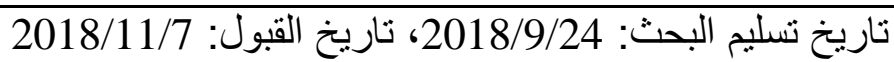

\section{REFERENCES}

Abdel Salam, Mohamed El Sayed. (2001), "Modern Technologyand Agricultural Development in the Arab World," Milestones of Knowledge, No. 50, Kuwait, p. 88.

Abu Al-Saud, Mohammed Al-Sayed (2010), "Technological Potential and Economic Growth," Arab Planning Institute, Kuwait, an independent Arab organization, No. 95, ninth year.

AL.Badri, Ahmed Hussein Nasser, "The Technological Gap in the Iraqi Agricultural Sector and its Economic Impacts", Research published at the Fifth Conference, Wasit University, 2012.

Ali and Hamid, Fayad Abdullah, AzabMezher (2010)"Transfer and Settlementof Technology and its Impacton Human Resources Development - An Applied TheoryStudy",Journal of Baghdad College of Economic Sciences, University,No259

Al-Rawi, Mansour (1987) "The Gap of Love in the Arab World - Reality and Horizons", Arab Economic Magazine, 11, p. 
Ansari, Asaad and Mahdi, Saleh (2010) "The Perspective of theTechnological Gap in a Knowledge Economy Environment", University of Basra, Wasit University.

Iyer,Kinshna .G(2006)"Technology Gap Gatching up and out ward orientation, Masser, University ,Palmerstion North ,Newzwaland.

Jumaili, Sami Humaid Abbas (1993), "The Role of Technology in Agricultural Development in the Arab World", PhD thesis, Faculty of Management and Economics, University of Baghdad,p85.

N.Kamieu (2010)" Tichnology Gap and Efficiency CocaProduction in west and central Africa,Implication For Coca SectorDevelopment" ,International ,Instiute of Tropical Agriculture,NO.104. 